\title{
Climate Impacts of the Biomass Burning in Indochina on Atmospheric Conditions over Southern China
}

\author{
Lina Huang ${ }^{1}$, Wenshi Lin ${ }^{1,2 *}$, Fangzhou $\mathrm{Li}^{3}$, Yuan Wang ${ }^{4}$, Baolin Jiang ${ }^{3}$ \\ ${ }^{1}$ School of Atmospheric Sciences and Guangdong Province Key Laboratory for Climate Change and Natural Disaster \\ Studies, Sun Yat-sen University, Guangzhou, Guangdong 510275, China \\ ${ }^{2}$ Southern Marine Science and Engineering Guangdong Laboratory (Zhuhai), Zhuhai 519082, China \\ ${ }^{3}$ School of Atmospheric Sciences, Sun Yat-sen University, Guangzhou 519082, China \\ ${ }^{4}$ Division of Geological and Planetary Sciences, California Institute of Technology, Pasadena, CA 91106, USA
}

\begin{abstract}
Substantial biomass burning (BB) activities in Indochina during March and April of each year generate aerosols that are transported via westerly winds to southern China. These BB aerosols have both radiative (direct and semi-direct) and indirect effects on the climate. This study evaluates impacts of BB in Indochina during April 2013 on atmospheric conditions in southern China using WRF-Chem sensitivity simulations. We show that the atmosphere becomes drier and hotter under the aerosol radiative effect in southern China, while the changes linked to the indirect effect are opposite. The former (the latter) rises (reduces) surface temperature $0.13^{\circ} \mathrm{C}\left(0.19^{\circ} \mathrm{C}\right)$ and decrease (increase) water vapor mixing ratios $0.23 \mathrm{~g} \mathrm{~kg}^{-1}\left(0.40 \mathrm{~g} \mathrm{~kg}^{-1}\right)$ at $700 \mathrm{hPa}$. Atmospheric responses to aerosols in turn affect aerosol dissipation. Specifically, BB aerosols absorb solar radiation and heat the local atmosphere, which inhibits the formation of clouds (reducing low-level cloud about $7 \%$ ) related to the aerosol semi-direct effect. Less cloud enhances surface solar radiation flux and temperature. Otherwise, northeasterly winds linked to radiative effect suppress water vapor transport. In this case, precipitation reduces $1.09 \mathrm{~mm}^{\text {day }}{ }^{-1}$, diminishing wet removal and westward transport of aerosols. Under the indirect effect, greater cloud coverage is formed, which reduces surface solar radiation flux and increases local latent heat release. This extra heating promotes air convection and diffusion of pollution. Regional mean precipitation increases $0.49 \mathrm{~mm} \mathrm{~d}^{-1}$, facilitating wet pollution removal. Under indirect effect, aerosol extinction coefficient reduces $0.011 \mathrm{~km}^{-1}$ at $2-\mathrm{km}$ height over southern China. However, it increases around $0.002 \mathrm{~km}^{-1}$ at $3-\mathrm{km}$ height over southernmost China related to radiative effect. Therefore, atmospheric changes linked to indirect effect play a greater role in removing pollutants from the atmosphere than radiative effect over southern China.
\end{abstract}

Keywords: Aerosol radiative effect; Aerosol indirect effect; Cloud cover; WRF-Chem; Latent heat.

\section{INTRODUCTION}

Biomass burning (BB) occurs in both natural and anthropogenic fires, such as forest or prairie fires, as well as burning of wood and agricultural waste to clear land, manage forests, and generate residential heating (Jacobson, 2012; Reid et al., 2013; Chen et al., 2016). Therefore, emissions from BB have characteristics of both natural and anthropogenic sources. In Asia, considerable BB occurs on the Indochina Peninsula, as well as in India, Russia, eastern Siberia, and on the Mongolian Plateau (Hao et al., 1994). A review of the Seven Southeast Asian Studies (7-SEAS) program by Reid et al. (2013) indicated that there was substantial BB on the

\footnotetext{
* Corresponding author.

Tel.: 0086-20-84110526

E-mail address: linwenshi@mail.sysu.edu.cn
}

Indochina Peninsula in drier seasons, related to agriculture being the dominant economic sector of Indochina. Typically, $\mathrm{BB}$ begins in the southernmost part of Indochina (Cambodia) in late December or early January, when the winter monsoon arrives. It propagates northward, peaking in March or April. With the onset of summer monsoons in early May, BB is discontinued until the following dry season. The annual variability of BB in Indochina reflects changes in the fuels' degree of dryness (Giglio et al., 2006a; Reid et al., 2013; Lin et al., 2014).

BB mainly emits gases, such as carbon dioxide $\left(\mathrm{CO}_{2}\right)$, carbon monoxide $(\mathrm{CO})$, and oxynitrides $\left(\mathrm{NO}_{x}\right)$, as well as aerosol particles, such as black carbon (BC) and organic carbon (OC) (Jacobson and Mark, 2012; Wang et al., 2015; Chen et al., 2016). Generally, BB emissions from Indochina are transported over the Tenasserim Hills and Annamite Range via deep convection, then transported by westerly winds in the middle-low troposphere to southern China (south of the Nanling Mountains) and the Pacific Ocean (Carmichael 
et al., 2003; Fu et al., 2012). Usually, these emissions enter China at heights of 850-700 hPa (Lin et al., 2014; Li et al., 2017). Sometimes, BB emissions from southern Indochina make their way to the South China Sea (SCS), traversing the large open plains of the Mekong River and Delta. In addition, there is a strong vertical wind shear over the northern SCS, with northeasterly winds occurring within the planetary boundary layer and strong westerly winds within the lower troposphere. The northeasterly winds bring pollution from the Pearl River Delta via the Beibu Gulf into northern Vietnam. Meanwhile, the westerly winds transport $\mathrm{BB}$ emissions into northern areas of the SCS and southern China (Reid et al., 2013; Lin et al., 2014). In the month of March, most BB aerosols are concentrated in southeast Asia and southern China. However, their influence could extend to the Yangtze River Delta region during the month of April (Fu et al., 2012).

$\mathrm{BB}$ aerosols include absorbing aerosols, like $\mathrm{BC}$, which absorb solar shortwave radiation, heating the local atmosphere and inhibiting cloud formation (Ackerman et al., 2000; Lau et al., 2006; Meehl et al., 2006; Wu et al., 2011a, b; Ding et al., 2016); this produces the "semi-direct effect" (Hansen et al., 1997). Scattering aerosols, like OC and sulfates, scatter solar radiation and prevent it from reaching the ground via the "aerosol direct effect" (Charlson et al., 1992; Wang et al., 2007; Zhang et al., 2008, 2009; Wu et al., 2011a, b; Pani et $a l ., 2018)$. Under this effect, both ground and near-surface atmospheric temperatures decrease. For simplicity, we use the 'aerosol radiative effect' to represent the overall impacts of both aerosol direct and semi-direct effects in this article. Typically, aerosols alter the atmospheric temperature lapse rate, stabilize the local atmosphere, and aggravate pollution (Zhang et al., 2008, 2009; Wu et al., 2011b; Ge et al., 2014; Ding et al., 2016). As Ding et al. (2016) stated, atmospheric $\mathrm{BC}$ aerosols have a "dome effect", with strong absorption of solar radiation, surface cooling and atmospheric heating within the lowest $1-2 \mathrm{~km}$ of the atmosphere. According to their results, this dome effect limits the development of the planetary boundary layer and increases urban pollution. Zhang et al. (2009) found that BB aerosols over the Amazon reduced the surface solar flux, while strong aerosol heat absorption stabilized the lower troposphere, producing anomalous wind divergence over the southern Amazon and anomalous air convergence over the upwind area. Ge et al. (2014) showed that smoke particles within and above lowlevel clouds produce a positive forcing at the top of the atmosphere, while smoke radiative extinction decreases land surface temperature. According to their results, the BB aerosol semi-direct effect is important during the daytime because it increases atmospheric stability and reduces cloud cover.

$\mathrm{BB}$ aerosols also can serve as cloud condensation nuclei (CCN) or ice nuclei (IN), affecting cloud microphysics and overall cloud albedo, which is described as the "first aerosol indirect effect" (Twomey, 1977). Finally, BB aerosols acting as $\mathrm{CCN}$ can alter precipitation rates, as well as the coverage and lifetime of clouds, which is described as the "second aerosol indirect effect" (Albrecht, 1989; Daniel et al., 2008). In general, BB aerosols acting as $\mathrm{CCN}$ induce increases in the cloud droplet number but decreases in the cloud droplet size and effective radius. Subsequently, the autoconversion process decelerates, suppressing precipitation (Ackerman et al., 2000; Tao et al., 2012; Lee et al., 2014). Wu et al. $(2011 \mathrm{a}, \mathrm{b})$ simulated the impacts of BB in South America during the dry season. They showed that marked reductions in cloud coverage and precipitation occurred at noon but increased again overnight. In this case, the aerosol radiative effect produced greater changes in atmospheric conditions than the counteracting aerosol indirect effect.

Diverse spatial gradients in BB aerosols over their source and downwind areas have variable influences on radiant flux and atmospheric circulation (Menon et al., 2002; Kim et al., 2006; Lee et al., 2015). Johnson et al. (2010) showed that the aerosol semi-direct effect on clouds and radiative forcing varied with different aerosol vertical distributions. Therefore, the aerosol effects are diverse over the BB source and downwind areas, especially over heterogeneous terrain.

An IPCC Special Report on the impacts of global warming of $1.5^{\circ} \mathrm{C}$ above pre-industrial levels states that increases of less than or equal to $1.5^{\circ} \mathrm{C}$ would avert more ecological damage than warming by $2^{\circ} \mathrm{C}$, including less sea level rise, less Arctic sea-ice melt and lower levels of coral reef extinction (IPCC, 2018). Reducing carbon emissions is one of the main pathways to achieve this outcome. As one of the important carbon emission sources, biomass burning not only affects local atmospheric conditions, but also their downwind areas. Southeast Asia, as the main biomass burning region worldwide, has a great impact on global warming. Meanwhile, Southeast Asia has been identified as one of the most vulnerable regions of the world to climate change (IPCC, 2007). Several field experiments in East Asia and Southeast Asia have investigated aerosols and trace gases, as well as their climatic effects, including TRACE-P (TRAnsport and Chemical Evolution over the Pacific), ACE-Asia (Aerosol Characterization Experiments in Asia), Project Atmospheric Brown Cloud (ABC), and the 7-SEAS (Huebert et al., 2003; Jacob et al., 2003; Spencer et al., 2008; Reid et al., 2013). TRACE-P was designed to study the effect of east Asian atmospheric pollutant emissions on the northwest Pacific Ocean (Jacob et al., 2003). The Project ABC was created to monitor changes in aerosols and cloud properties over Indo Asian and Pacific regions to better understand the influence of rising air pollution on regional and global environments (Spencer et al., 2008). The 7-SEAS, involving seven regional science partners (Indonesia, Malaysia, Philippines, Singapore, Taiwan, Thailand and Vietnam), was designed to understand the aerosol chemical, optical and physical properties in Southeast Asia (Reid et al., 2013; Lin et al., 2014). Lin et al. (2014) reviewed remote sensing observations, modeling, and regional field studies focused on the 7-SEAS study area.

Many previous studies have shown that BB aerosols affect cloud microphysics processes and the radiation balance, altering atmospheric conditions and precipitation patterns. Relatively few studies have quantitatively studied BB aerosol radiative and indirect effects on the regional atmospheric circulation over Indochina. Thus, we used the Weather Research and Forecasting model, coupled with Chemistry (WRF-Chem, version 3.5.1), to study the impacts of BB on the Indochina Peninsula under spring atmospheric conditions over Indochina and southern China, related to both aerosol 
radiative and indirect effects. We carried out an initial case study using data for April 2013. This study provides a strong foundation for future research on the impacts of $\mathrm{BB}$ on climate in southern China.

\section{DATA AND METHODS}

\section{Model and Design of Numerical Experiment}

The online version of the WRF-Chem model was used to study atmospheric conditions for April 2013; it can simulate transport, mixing, and chemical transformation of trace gases and aerosols simultaneously (Grell et al., 2005). Major physical schemes of the model include the Grell-Devenyi ensemble cumulus parameterization scheme (Grell and Dévényi, 2002), the Lin microphysics scheme (Lin et al., 1983), the Rapid Radiative Transfer Model for Global Climate Models shortwave/longwave radiation scheme (Mlawer et al., 1997; Iacono et al., 2000), the Yonsei University planetary boundary layer scheme (Hong et al., 2006), and the Noah land-surface module (Chen and Dudhia, 2001; Ek et al., 2003). The chemical mechanism used is based on the Regional Acid Deposition Model version 2 (Chang et al., 1987), coupled with the Modal Aerosol Dynamics Model for Europe and Secondary Organic Aerosol Model (MADE/SORGAM) (Ackerman et al., 1998; Schell et al., 2001). The MADE/ SORGAM simulates all major aerosol components, including sulfate, nitrate, ammonium, BC, OC, sodium, chloride, mineral dust, and water content.

The model domain of this case study (Fig. 1) covers most of China, Indochina, the Philippines, the Bay of Bengal, the SCS, and the northwestern Pacific Ocean. The horizontal resolution is $45 \mathrm{~km}$, with $139 \times 100$ grid points. Given that we were most interested in Indochina and southern China, we selected the subregion, defined by $3-40^{\circ} \mathrm{N}$ and $80-140^{\circ} \mathrm{E}$ to analyze in detail (shown by the black rectangle outlined in Fig. 1). In addition, we defined the region from $21^{\circ} \mathrm{N}$ to $27^{\circ} \mathrm{N}$ and from $107^{\circ} \mathrm{E}$ to $117^{\circ} \mathrm{E}$, as representative of southern China (shown by the black dashed box in Fig. 1). The initial and boundary conditions were interpolated using the US
National Center for Environmental Prediction Final Reanalysis Data (http://dss.ucar.edu/datasets/ds083.2). We selected data for April 2013 because it is just before the Asian tropical summer monsoon onset. At this time, southwesterly winds are stronger than in March. Meanwhile, BB has not yet ceased in Indochina, because the summer monsoon onset is in May. In addition to the control experiment (CTL), incorporating both aerosol radiative and indirect effects simultaneously, two sensitivity experiments explored radiative and indirect effects individually. The no-aerosol-radiativeeffect (NORA) experiment turned off radiative feedback from aerosols in the radiation scheme, producing neither direct nor semi-direct effects; while the no-aerosol-indirecteffect (NOIND) experiment turned off chemistry and microphysical interactions between aerosols and clouds. Therefore, the BB aerosol radiative effect includes both direct and semi-direct effects, estimated using the difference between CTL and NORA model results. Similarly, the CTL minus NOIND model results estimated the aerosol indirect effect within the region.

\section{Biomass Burning Emissions Data}

We used the Global Fire Assimilation System (GFAS v1.0) for BB emission data, made available through the Monitoring Atmospheric Composition and Climate-Interim Implementation II project of the European Center for Medium-Range Weather Forecasts (Giglio et al., 2006b; Kaiser et al., 2012). GFAS v1.0 calculates BB emissions by assimilating fire radiative power observations from the MODerate-resolution Imaging Spectroradiometer (MODIS) instruments onboard the Terra and Aqua satellites. The system corrects for gaps in observations (mostly related to cloud cover) and filters out spurious observations linked to volcanoes, gas flares, and industrial activities. The combustion rate is calculated using land cover-specific conversion factors. Wildfire emission factors for 40 gas-phase and aerosol trace species were compiled from a literature survey, providing values for $\mathrm{BC}, \mathrm{OC}, \mathrm{CO}_{2}$ and several other relevant species. Daily emissions were calculated on a global $0.5^{\circ} \times 0.5^{\circ}$ grid

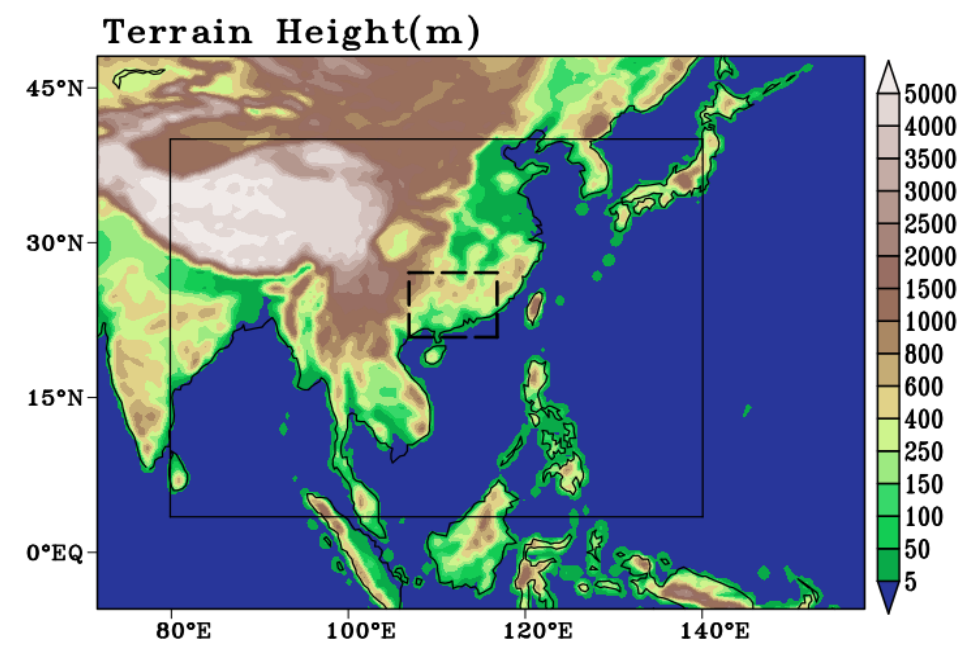

Fig. 1. The model domain and terrain height $(\mathrm{m})$ used for the study region of southern China defined by $21-27^{\circ} \mathrm{N}$ and $107-$ $117^{\circ} \mathrm{E}$ (shown as the black dashed box). 
from 2003 to the present (Flemming, 2012; Andela et al., 2013; Kaiser et al., 2013). BC levels from GFAS v1.0 data were used to represent BB emissions in this study.

\section{RESULTS AND DISCUSSION}

\section{Biomass-burning Emissions}

Generally, BB emissions from Indochina increase from December, then peak in March or April, and subsequently decrease rapidly with the onset of the summer monsoon. By May, there are few BB emissions. During the rainy season, no BB emissions occur on the Indochina Peninsula.

Figs. 2(a)-2(d) shows monthly average BB emissions of $\mathrm{BC}, \mathrm{OC}, \mathrm{CO}$, and particulate matter having less than $2.5-\mu \mathrm{m}$ diameter $\left(\mathrm{PM}_{2.5}\right)$ from GFAS data for April 2013. There were more aerosols and trace gases over northern Indochina than other Southeast Asia, with northern Laos having the highest levels (BC: $0.05 \mu \mathrm{g} \mathrm{m}^{-2} \mathrm{~s}^{-1}$; OC: $0.25 \mu \mathrm{g} \mathrm{m}^{-2} \mathrm{~s}^{-1}$; CO: $1.5 \mu \mathrm{g} \mathrm{m}^{-2} \mathrm{~s}^{-1}$; and $\mathrm{PM}_{2.5}: 0.5 \mu \mathrm{g} \mathrm{m}^{-2} \mathrm{~s}^{-1}$ ). Myanmar and Vietnam had slightly lower $\mathrm{BB}$ aerosol concentrations than Laos, with $\mathrm{BC}$ values of $0.02 \mu \mathrm{g} \mathrm{m}^{-2} \mathrm{~s}^{-1}$. Less BB occurred in China and India than in Indochina during April 2013.

\section{Model Evaluation}

Reanalysis (Figs. 3(a) and 3(c)) and simulated CTL experiment (Figs. 3(b) and 3(d)) monthly averaged geopotential height and wind field data are shown at $850 \mathrm{hPa}$ (panels (a) and (b)) and $200 \mathrm{hPa}$ (panels (c) and (d)) for April 2013. The reanalysis data were obtained from ERA-Interim.

At $850 \mathrm{hPa}$, there was an anticyclonic circulation in the reanalysis wind field over east India. Strong westerly winds occurring north of the anticyclonic circulation were displaced eastwards but were blocked by the Tibetan Plateau. This forced some of the air mass to flow southward to the Bay of Bengal, while some flowed eastwards around the Tibetan Plateau and formed cyclonic shear over northern Indochina, generating strong southwesterly winds over southern China. In other instances, the subtropical high over the SCS produced strong southwesterly winds over southern China. Because the southwesterly wind regime over northern Indochina coincides with its major BB emission period (Fig. 2), abundant BB aerosols are transported to southern China (Fig. 4(a)).

Meanwhile, at heights of $200 \mathrm{hPa}$, the area north of $15^{\circ} \mathrm{N}$ was dominated by westerly winds, related to strong westerly jets over the area around $30^{\circ} \mathrm{N}$. In contrast, an easterly wind regime occurred across almost all tropical regions. The Pacific subtropical high, located east of the Philippines, produced southwesterly winds over both Indochina and southern China.

Although the model had enhanced northwesterly flow at $850 \mathrm{hPa}$ over northern China and reduced easterly flow over the tropical Pacific Ocean compared with measured values, (a) GFAS-BC $(\mu \mathrm{g} / \mathrm{m} 2 / \mathrm{s})$

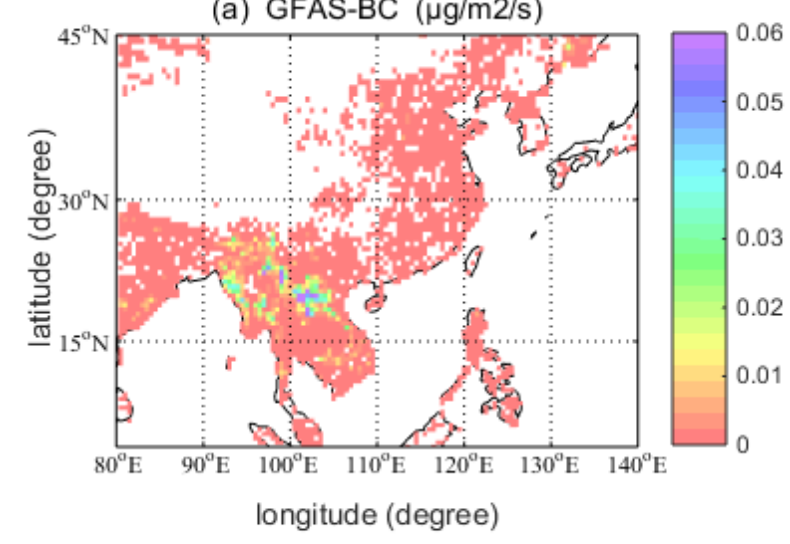

(c) GFAS-CO $(\mu \mathrm{g} / \mathrm{m} 2 / \mathrm{s})$

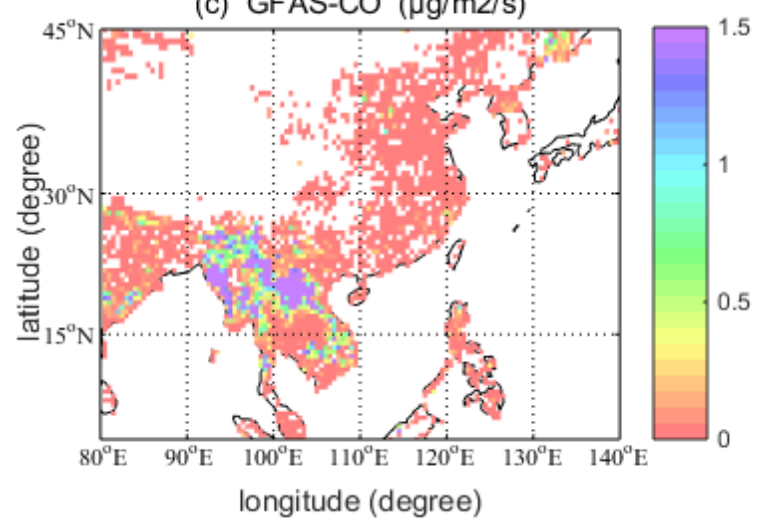

(b) GFAS-OC $(\mu \mathrm{g} / \mathrm{m} 2 / \mathrm{s})$

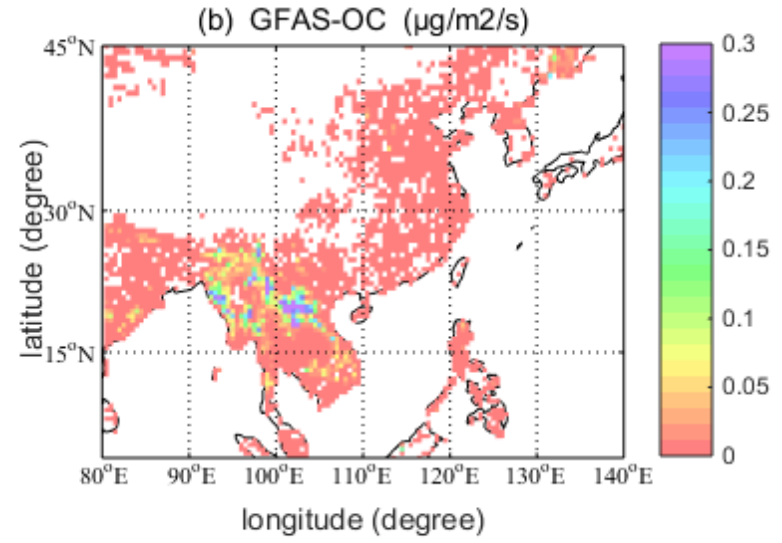

(d) GFAS-PM2.5 $(\mu \mathrm{g} / \mathrm{m} 2 / \mathrm{s})$

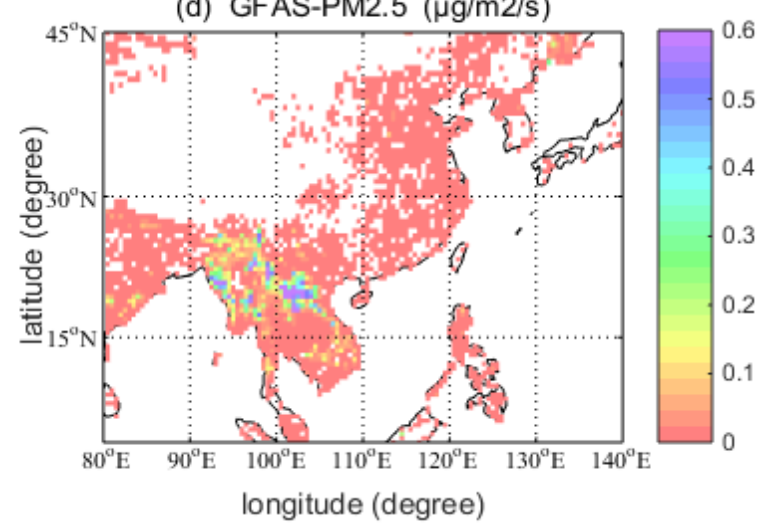

Fig. 2. Monthly averaged biomass burning emissions $\left(\mu \mathrm{g} \mathrm{m}^{-2} \mathrm{~s}^{-1}\right)$ of black carbon (BC), organic carbon (OC), carbon monoxide (CO), and particulate matter less than $2.5 \mu \mathrm{m}$ in diameter $\left(\mathrm{PM}_{2.5}\right)$ from the Global Fire Assimilation System (GFAS v1.0) for April 2013. 
(a)ERA-Interim $850 \mathrm{hPa}$

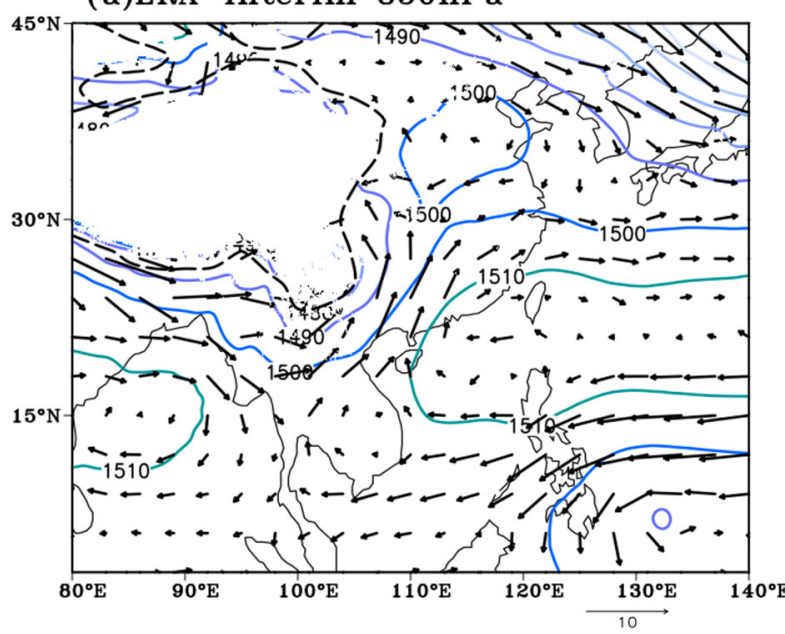

(c)ERA-Interim $200 \mathrm{hPa}$

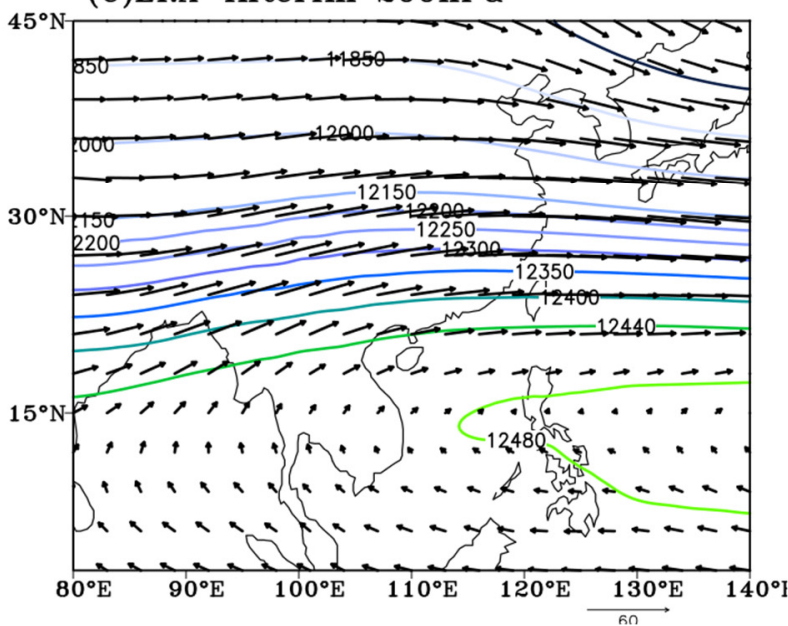

(b)CTL $850 \mathrm{hPa}$

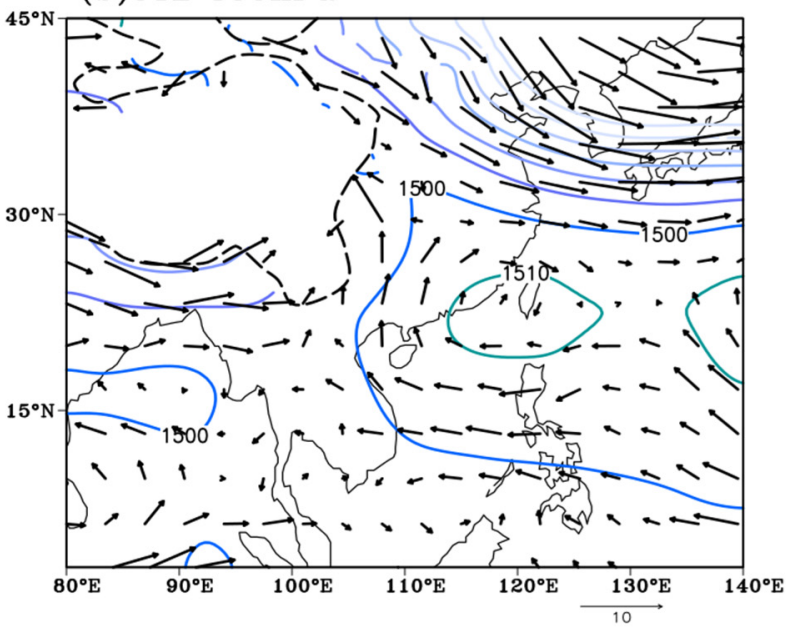

(d)CTL $200 \mathrm{hPa}$

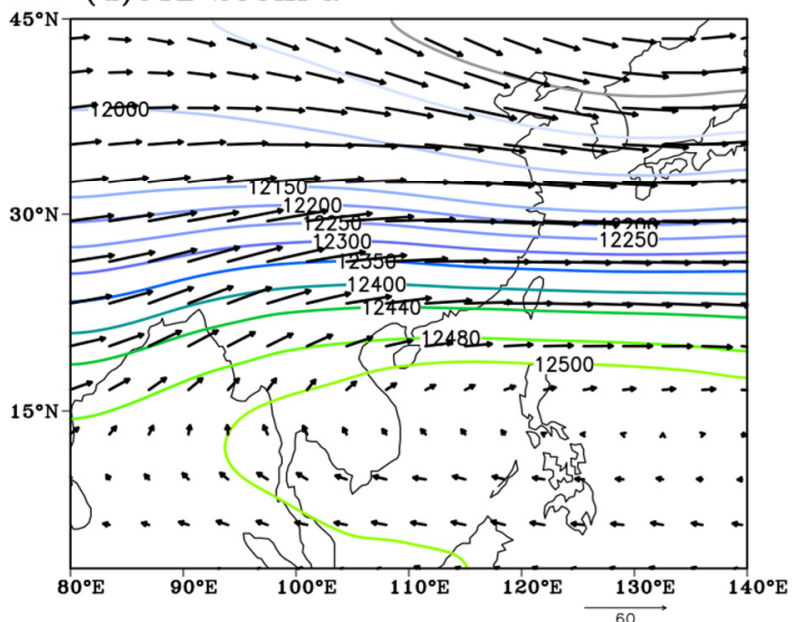

Fig. 3. Reanalysis and simulated monthly average geopotential height (contours, gpm) and wind field (arrows, $\mathrm{m} \mathrm{s}^{-1}$ ) at heights of $850 \mathrm{hPa}$ and $200 \mathrm{hPa}$ for April 2013.

it was able to reproduce the major atmospheric circulation patterns and geopotential height over Indochina and southern China for April 2013.

\section{Analysis \\ The Vertical Distribution of PM2.5}

The results of the CTL experiment are shown in Fig. 4 along a monthly-averaged vertical cross section of (a) $\mathrm{PM}_{2.5}$ aerosol dry mass (shading, $\mu \mathrm{g} \mathrm{m}^{-3}$ ) and atmospheric zonalvertical circulation (arrows) and (b) liquid water content (LWC; shading, $\mathrm{mg} \mathrm{kg}^{-1}$ ); meridional averaging was performed from $20^{\circ} \mathrm{N}$ to $30^{\circ} \mathrm{N}$. Based on the atmospheric circulation described in Fig. 4(a) and model results of the previous section, aerosols ascended via updrafts over the mountains in northern Indochina, and then traveled via tropospheric westerly winds to southern China and northern Pacific Ocean regions. There were substantial concentrations of $\mathrm{PM}_{2.5}$ aerosols over northern Indochina, with concentrations of more than $50 \mu \mathrm{g} \mathrm{m}^{-3}$ near the surface ( $2-\mathrm{km}$ height); however, these aerosol concentrations decreased with height. In contrast, aerosol concentrations first increased and then decreased with height over southern China, with the maximum concentration occurring at $\sim 2-\mathrm{km}$ height. Therefore, the location of the maximum concentration of BB aerosols $\left(\sim 12 \mu \mathrm{g} \mathrm{m}^{-3}\right)$ was consistent with the peak LWC (Fig. 4(b)), which included both cloud water and rainwater at around 2-km height over northern Indochina and southern China. Furthermore, because the planetary boundary layer had a prevailing easterly wind, in contrast to the tropospheric westerly wind, less smoke pollution was transported from Indochina to southern China within the planetary boundary layer.

\section{Biomass-burning Aerosol Effects on Clouds}

The model results for low-level cloud fractions of CTL minus NORA and CTL minus NOIND are shown in Figs. 5(a) and 5(b). These distributions show changes of monthly average low-level cloud fractions related to the aerosol radiative and indirect effects, respectively. The BB aerosol radiative effect reduced low-level clouds (around $7 \%$ ) over southern China, as well as over relatively highaltitude areas of Indochina, such as the Annamite Range and the Tenasserim Hills (Fig. 5(a)). This reflects the coincidence of higher concentrations of BB aerosols (Fig. 4(a)) and warm cloud droplets (Fig. 4(b)) at around 2-km height. In 

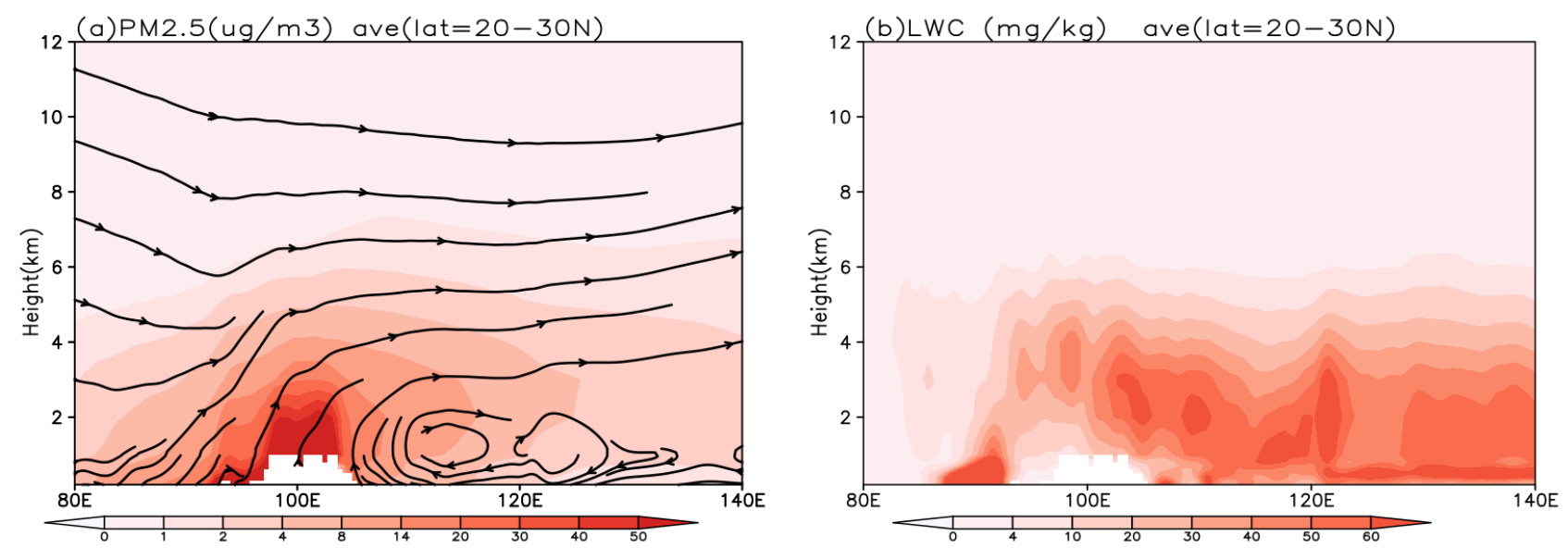

Fig. 4. Model results for the control (CTL) showing monthly average (a) $\mathrm{PM}_{2.5}$ aerosol dry mass (shading, $\mu \mathrm{g} \mathrm{m}^{-3}$ ) and atmospheric zonal-vertical circulation (arrows, $\mathrm{m} \mathrm{s}^{-1}$ ) and (b) liquid water content $\left(\mathrm{mg} \mathrm{kg}^{-1}\right)$; meridional averaging was performed from $20^{\circ} \mathrm{N}$ to $30^{\circ} \mathrm{N}$.

(a)Low Cloud Fraction(\%)

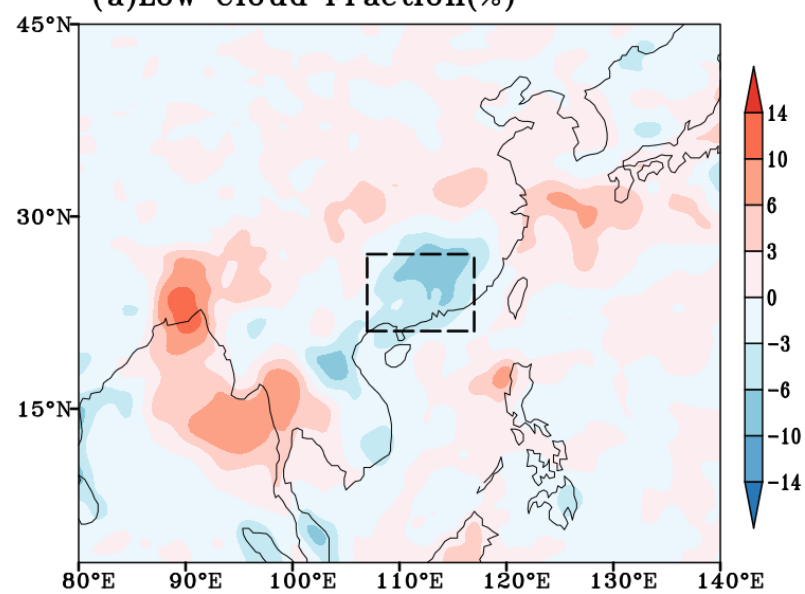

(b)Low Cloud Fraction(\%)

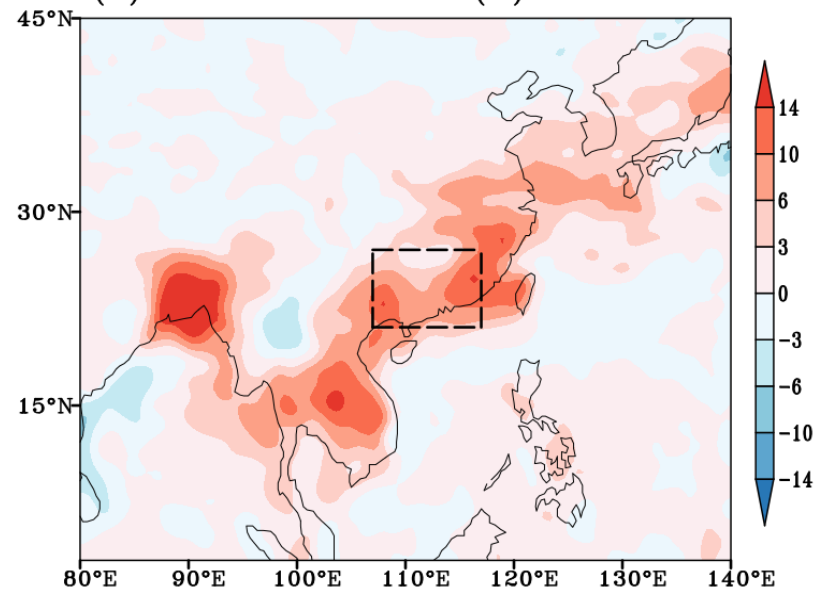

Fig. 5. Model results of monthly average low-level cloud fraction (\%) for (a) the control (CTL) minus the no-aerosolradiative-effect (NORA) and (b) the CTL minus the no-aerosol-indirect-effect (NOIND), representing the aerosol radiative and indirect effects, respectively.

such cases, BB aerosols absorbed abundant solar radiation and heated the local atmosphere, vaporizing cloud droplets related to the aerosol semi-direct effect. Evaporation of cloud droplets reduced the LWC, as seen in Fig. 6(a) (black solid line), in southern China. Meanwhile, evaporation cooling caused latent heating to become negative in Fig. 6(c) (black solid line). This variation in BB aerosols and cloud droplets is similar to the results of Lee et al. (2015), describing the influence of spatial gradients of BB aerosols on mesoscale circulations and clouds in the Amazon. Compared with low-level BB emissions, the BB emissions at around $1.5-\mathrm{km}$ height formed less cloud over the source region. In addition, low-level cloud formation was enhanced in low-altitude areas of southwestern Indochina. This increase in low-level cloud was related to the coincidence of the maximum aerosol concentration over southwestern Indochina being below $1-\mathrm{km}$ height, to the higher humidity (see the change of water vapor mixing ratio at $700 \mathrm{hPa}$ in Fig. 7(a)) and to changes in atmospheric circulation.
Related to the aerosol indirect effect, BB aerosols acting as $\mathrm{CCN}$ increased the number of cloud droplets and cloud cover (Fig. 5(b)) over most of Indochina and southern China (increasing low-level cloud 10\%). However, there was less cloud over northern Indochina, likely related to reduced moisture (Fig. 7(b)).

\section{Biomass-burning Aerosol Effects on Surface Thermal Fields}

The model results for shortwave downward radiation at the surface (SWDOWN) of CTL minus NORA and CTL minus NOIND are shown in Figs. 8(a) and 8(b). Clouds play an important role within the earth-atmosphere radiation budget. In particular, warm liquid clouds have a great effect on the SWDOWN (Rieland and Stuhlmann, 1993; Matus, et al., 2017). Generally, the variation observed for low-level clouds having high LWC was opposite to that of the SWDOWN, according to Figs. 5 and 8. The BB aerosol radiative effect reduced the SWDOWN by nearly $20 \mathrm{~W} \mathrm{~m}^{-2}$ 
(a) LWC (unit:mg/kg)

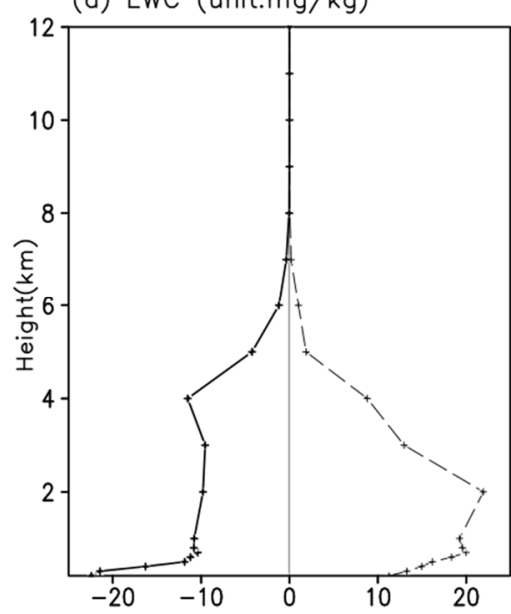

(b)IWC (unit:mg/kg)

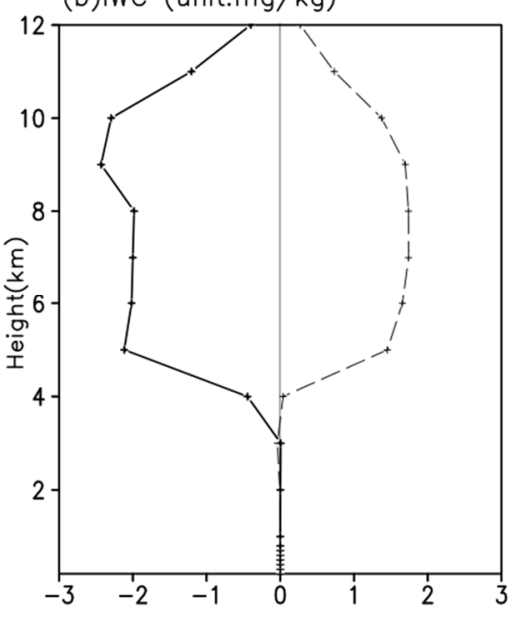

(c)H_diabatic (unit:K/d)

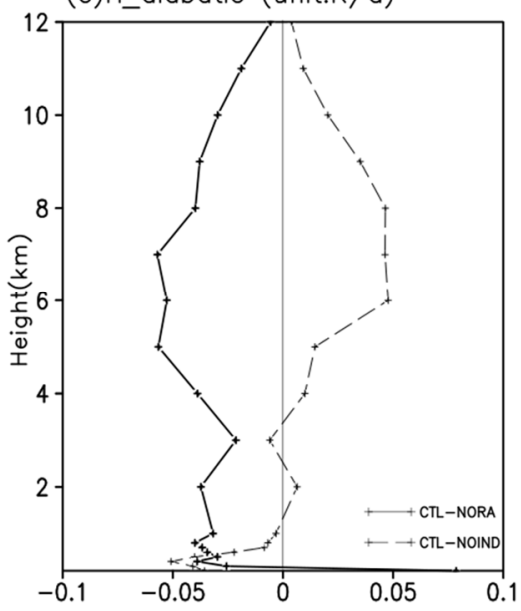

Fig. 6. Control (CTL) minus the no-aerosol-radiative-effect (NORA) model results representing the aerosol radiative effect as a black solid line and the CTL minus the no-aerosol-indirect-effect (NOIND) model results representing the aerosol

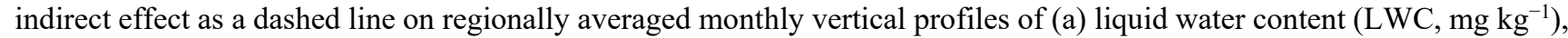
(b) ice water content (IWC, $\mathrm{mg} \mathrm{kg}^{-1}$ ) and (c) microphysical latent heating ( $\mathrm{K} \mathrm{day}^{-1}$ ) in southern China (defined by $21-27^{\circ} \mathrm{N}$ and $\left.107-117^{\circ} \mathrm{E}\right)$.

(a) Qvapor $(\mathrm{g} / \mathrm{kg})$

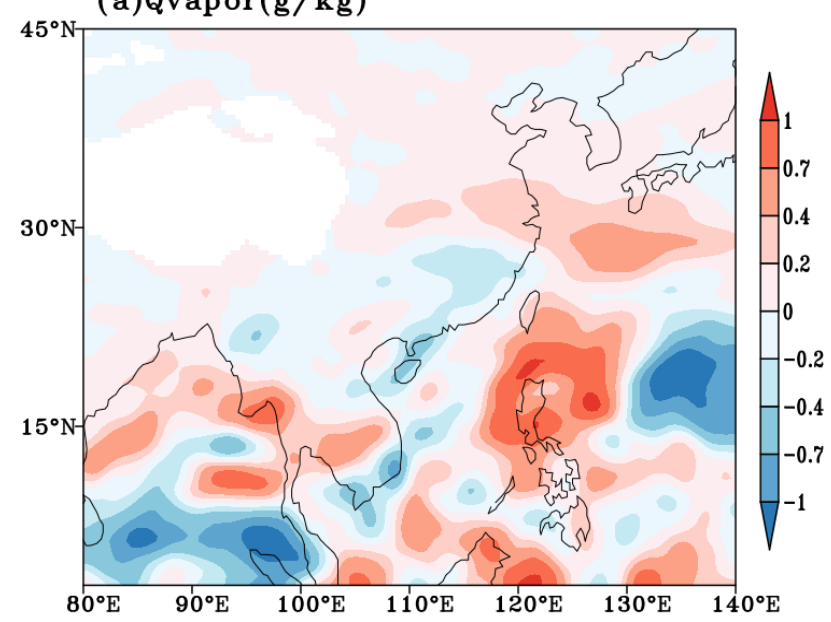

(b)Qvapor $(\mathrm{g} / \mathrm{kg})$

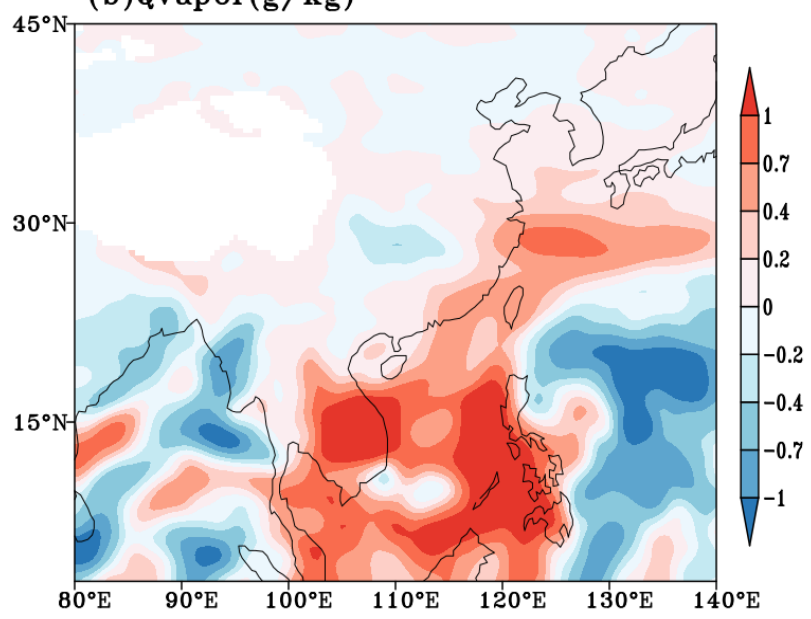

Fig. 7. Model results of the water vapor mixing ratio $\left(\mathrm{g} \mathrm{kg}^{-1}\right)$ at $700 \mathrm{hPa}$ for (a) the control (CTL) minus the no-aerosolradiative-effect (NORA) and (b) the CTL minus the no-aerosol-indirect-effect (NOIND), representing the aerosol radiative and indirect effects, respectively.

over Indochina (Fig. 8(a)), which is equivalent to the magnitude reported in the study of Lee et al. (2014). Firstly, this decrease was related to the increase of low-level clouds in southwestern Indochina that reflected more solar radiation. Secondly, given the substantial concentrations of aerosols over northern Indochina, their direct scattering of the solar radiation decreased the SWDOWN. Thus, despite the reduction in clouds, the aerosol direct effect played the major role of altering the SWDOWN and surface temperature over northern Indochina. In contrast, the SWDOWN increased by almost $9 \mathrm{~W} \mathrm{~m}^{-2}$ over southern areas of the Yangtze River in China (increasing the southern China regional mean by $8.97 \mathrm{~W} \mathrm{~m}^{-2}$ ) and $\sim 3 \mathrm{~W} \mathrm{~m}^{-2}$ over the Annamite Range. This was mainly because less low-level cloud allowed more solar radiation to reach the surface. The reduction in low-level clouds related to aerosol heat absorption contributed more to this change in the SWDOWN over southern China than the aerosol direct effect.

Focusing on the BB aerosol indirect effect, Fig. 8(b) shows that the SWDOWN was reduced over central and southern Indochina (by $\sim 25 \mathrm{~W} \mathrm{~m}^{-2}$ ) as well as southern China (reducing the regional mean by $27.46 \mathrm{~W} \mathrm{~m}^{-2}$ ), consistent with the increase in low-level clouds (Fig. 5(b)).

Next, we studied how surface temperature varied related to aerosol radiative and indirect effects (Fig. 9). The model results for surface temperature of CTL minus NORA and CTL minus NOIND are shown in Figs. 9(a) and 9(b). Under the influence of the aerosol radiative effect, the surface temperature variation was consistent with the spatial changes of the SWDOWN, with temperature reductions of $\sim 0.6^{\circ} \mathrm{C}$ 
(a)SWDOWN(W m^-2)

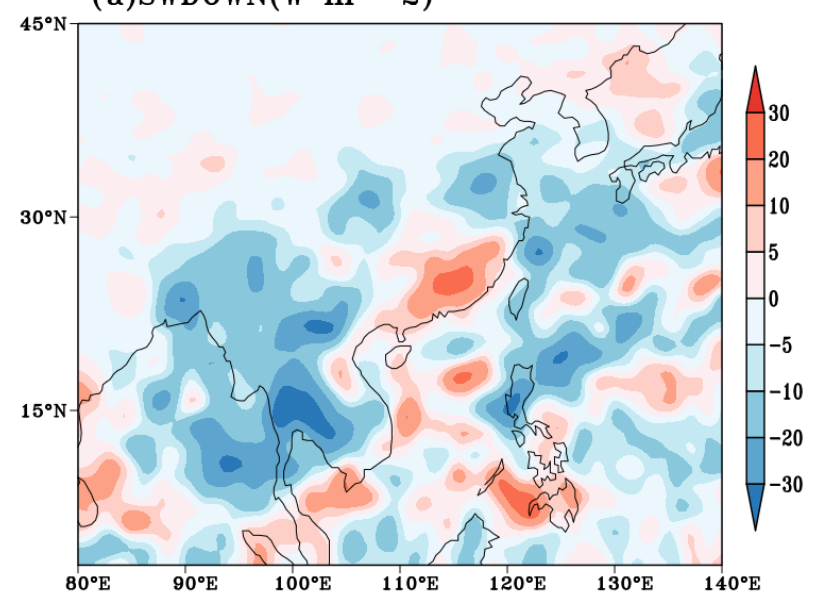

(b)SWDOWN(W $\mathrm{m} \sim-2)$

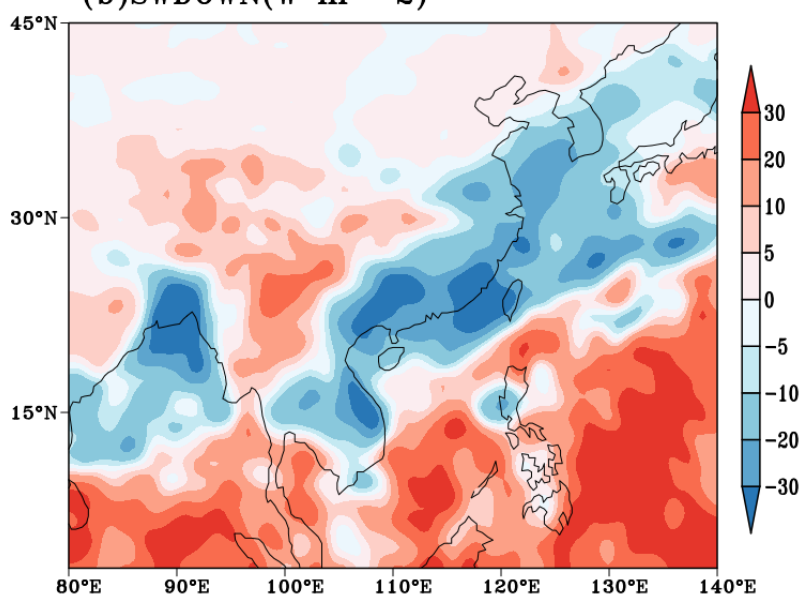

Fig. 8. Model results for shortwave downward radiation at the surface (SWDOWN, $\mathrm{W} \mathrm{m}^{-2}$ ) for (a) the control (CTL) minus the no-aerosol-radiative-effect (NORA) and (b) the CTL minus the no-aerosol-indirect-effect (NOIND), representing the aerosol radiative and indirect effects, respectively.

(a)T2(C)

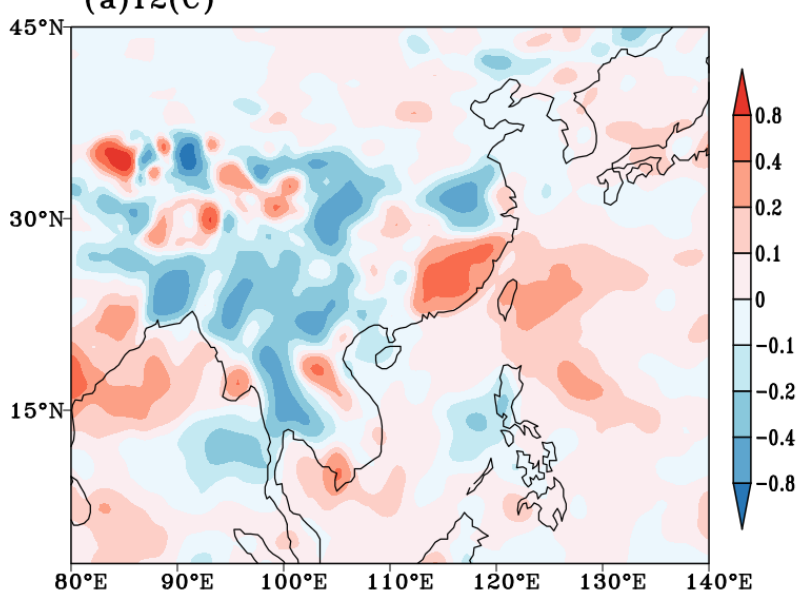

(b)T2(C)

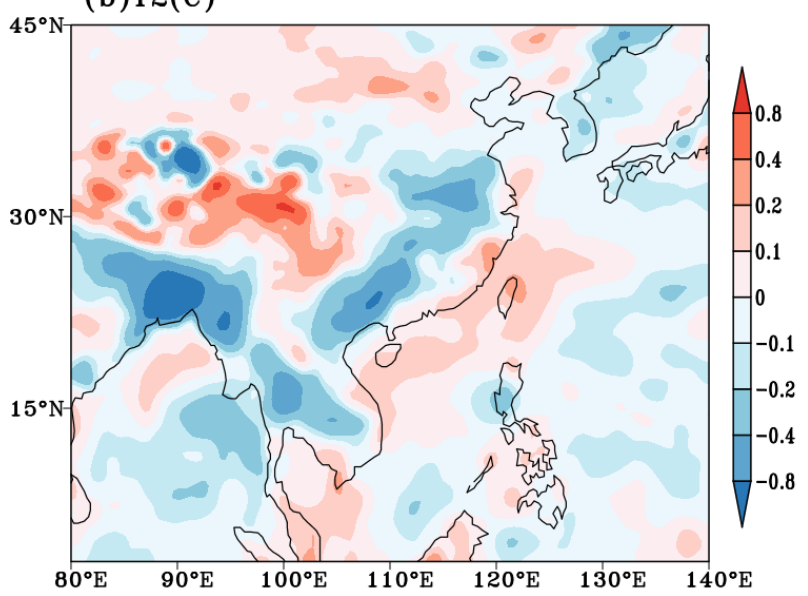

Fig. 9. Model results for surface temperature $\left({ }^{\circ} \mathrm{C}\right)$ for $(\mathrm{a})$ the control (CTL) minus the no-aerosol-radiative-effect (NORA) and (b) the CTL minus the no-aerosol-indirect-effect (NOIND), representing the aerosol radiative and indirect effects, respectively.

over most of Indochina but rising temperature over southern China (a regional mean increase of $0.13^{\circ} \mathrm{C}$ ) and southeastern Indochina (an increase of about $0.1^{\circ} \mathrm{C}$ ).

The $\mathrm{BB}$ aerosol indirect effect cooled the near-surface atmosphere over southern China (reducing the regional mean by $0.19^{\circ} \mathrm{C}$ ) and most of Indochina (Fig. 9(b)). This cooling mainly occurred over valleys and plains in Indochina, linked to changes in the SWDOWN. Surface temperature increased slightly in coastal regions of southern China, most likely because of warm air advection in the lower troposphere (Fig. 10(b)). Likewise, surface temperature rose slightly over the Annamite Range, Tenasserim Hills, and Hengduan Mountains, coincident with an increase in sensible heat (not shown).

Generally, the variation in surface temperature and SWDOWN related to the aerosol radiative and indirect effects had similar magnitudes. Clearly, the aerosol semidirect effect played a major role, altering cloud character and changing solar radiation and heat flux values.

\section{Biomass-burning Aerosol Effects on Circulation in the Lower Troposphere and Precipitation}

The model results for geopotential height and wind fields (at $850 \mathrm{hPa}$ ) of CTL minus NORA and CTL minus NOIND are shown in Figs. 10(a) and 10(b). Results show that geopotential height decreased to form an anomalous cyclonic circulation over southern Indochina in Fig. 10(a), related to the $\mathrm{BB}$ aerosol radiative effect. This is attributed to convection promoted by surface warming of southeastern Indochina (Fig. 9(a)). Combined with topographic-related updrafts of the Annamite Range and Tenasserim Hills, less air remained in the lower troposphere, causing the pressure to reduce and the air to converge to form an anomalous cyclonic circulation over southern Indochina. This cyclonic circulation enhanced updrafts (not shown) and induced more cloud formation (Fig. 5(a)). The northeasterly winds over 
southern China weakened the southwesterly winds (Fig. 3(b)), inhibiting westward transport of aerosols and water vapor to southern China.

The aerosol indirect effect on the geopotential height and wind fields shown in Fig. 10(b) is similar to that of the aerosol radiative effect shown in Fig. 10(a) over southern Indochina. Perhaps the uplift of the mountains played an important role in changing the wind field, unrelated to either aerosol radiative or indirect effects. In Fig. 10(b), an increase in cloud droplets plus topographic lifting induced more precipitation (Fig. 11(b)) and latent heating (not shown), which in turn fueled convection. Thus, the air pressure fell, forming cyclonic circulation in the lower troposphere over southern Indochina. Less change to the wind field occurred over southern China.

Temperature and wind field anomalies greatly affected atmospheric and water circulation patterns. Model results for water vapor mixing ratios and precipitation of CTL minus
NORA and CTL minus NOIND are shown in Fig. 7 and 11. The aerosol radiative effect on precipitation in Fig. 11(a) shows that the mean monthly precipitation increased over most of the plains in southern Indochina, related to more clouds and higher moisture content (Fig. 7(a)), as well as stronger air convergence patterns (Fig. 10(a)). However, there was less rain over northeastern Indochina, Yunnan Province, and southern China (resulting in a regional mean reduction in precipitation of $1.09 \mathrm{~mm} \mathrm{~d}^{-1}$ in southern China). The cloud decrease related to the aerosol semi-direct effect was one of the main reasons for these reductions. In addition, there was lower water vapor content (with water vapor mixing ratios decreased $0.23 \mathrm{~g} \mathrm{~kg}^{-1}$ in Fig. 7(a)) related to the northeasterly wind regime (Fig. 10(a)) in the lower troposphere of southern China, inhibiting transport of moist air to southern China.

Related to the aerosol indirect effect, BB aerosols acting as $\mathrm{CCN}$ increased cloud droplet number concentrations and reduced the cloud droplet effective radius, which decelerated
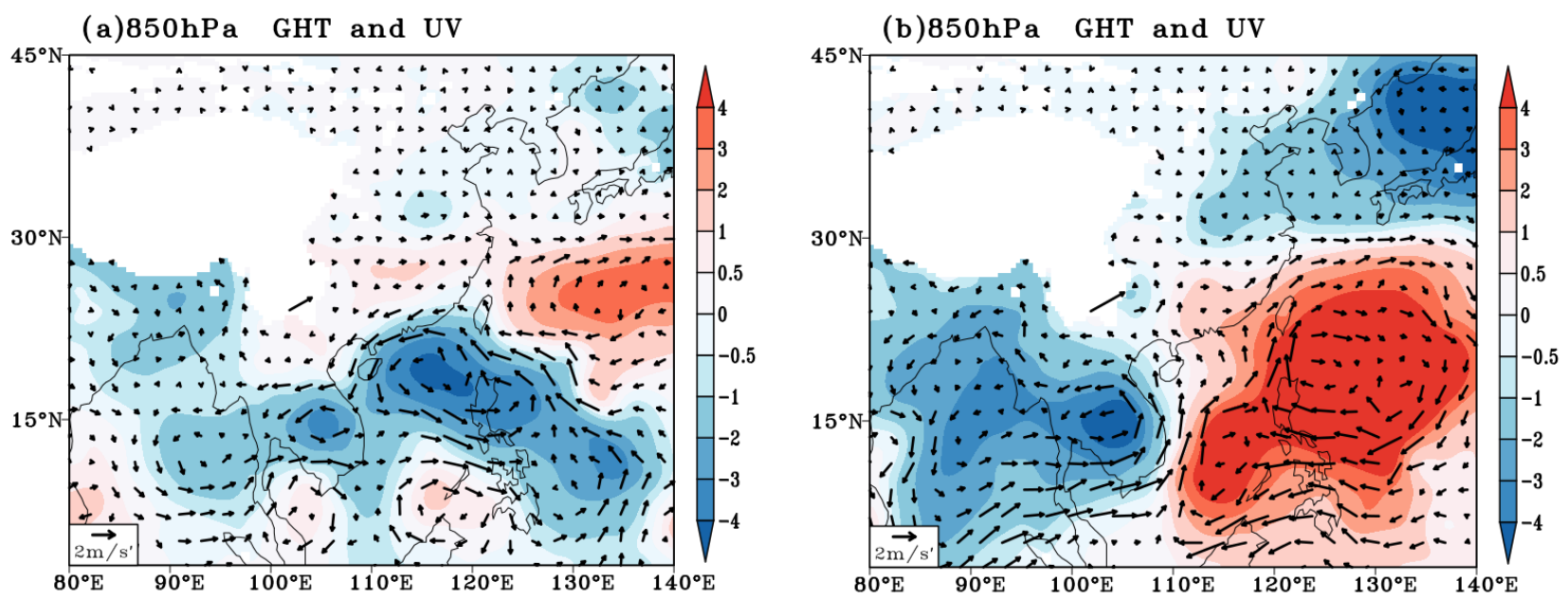

Fig. 10. Model results for geopotential height (shading, gpm) and wind field (arrows, $\mathrm{m} \mathrm{s}^{-1}$ ) at a height of $850 \mathrm{hPa}$ for (a) the control (CTL) minus the no-aerosol-radiative-effect (NORA) and (b) the CTL minus the no-aerosol-indirect-effect (NOIND), representing the aerosol radiative and indirect effects, respectively.

\section{(a)precipitation $(\mathrm{mm} /$ day)}

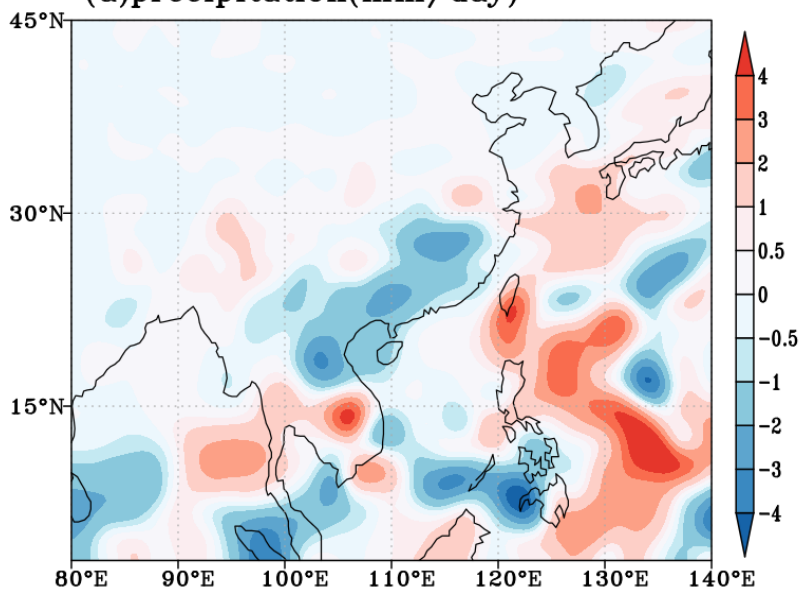

(b)precipitation $(\mathrm{mm} / \mathrm{day})$

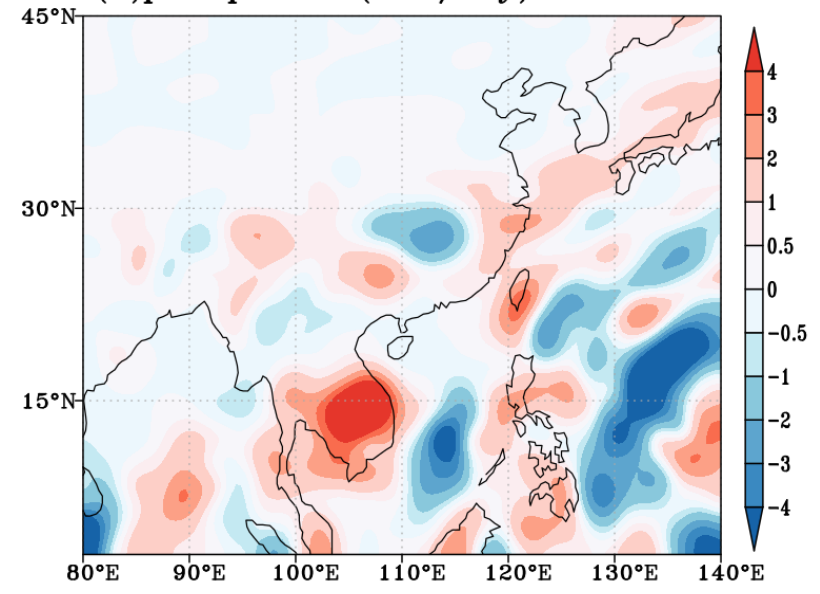

Fig. 11. Model results for precipitation $\left(\mathrm{mm} \mathrm{day}^{-1}\right.$ ) for (a) the control (CTL) minus the no-aerosol-radiative-effect (NORA) and (b) the CTL minus the no-aerosol-indirect-effect (NOIND), representing the aerosol radiative and indirect effects, respectively. 
the autoconversion of cloud water into rain, reducing precipitation. Precipitation was reduced over middle reaches of the Yangtze River (Fig. 11(b)), with greater reductions in rainwater than in cloud water (not shown). Water vapor decreases (Fig. 7(b)) in this region also severely inhibited rain formation. Aerosols clearly effect orographic cloud and precipitation formation (Daniel et al., 2007; Fan et al., 2014; Xiao et al., 2014, 2015). The updrafts and convergence related to local mountains likely caused warm and moist air to ascend, facilitating extension and development of clouds, and promoting coalescence of cloud droplets to form rain. Under the aerosol indirect effect, updrafts were enhanced (not shown), which induced strong versus slight increases in precipitation over southern Indochina $\left(\sim 4 \mathrm{~mm} \mathrm{~d}^{-1}\right)$ and Guangxi Province (increasing the southern China regional mean precipitation by $0.49 \mathrm{~mm} \mathrm{~d}^{-1}$ ), respectively. These areas are both located on the windward slopes of mountains. Finally, Fig. 11(b) shows that less precipitation occurred over northern Indochina because of less moisture in the air (Fig. 7(b)).

\section{Biomass-burning Aerosol Effects on Vertical Profiles of Selected Meteorological Variables}

The change in mean monthly temperature as vertical profiles over southern China is shown in Fig. 12(a) for the black box region of Fig. 5. The solid line represents the variation caused by the aerosol radiative effect, while the dashed one represents the aerosol indirect effect. There was only a small change in temperature in the lower and middle troposphere of southern China related to the aerosol radiative effect. This is likely because of opposing impacts of the aerosol semi-direct effect and microphysical latent heating, producing balanced heating and cooling effects. Although there was an increase in temperature within the planetary boundary layer over southern China, this layer was too thin to promote convection. Coupled with the reduction in clouds, this led to less latent heat release (solid line in Fig. 6(c)) and weaker convection, producing an atmosphere that was more

(a) T (unit:C)

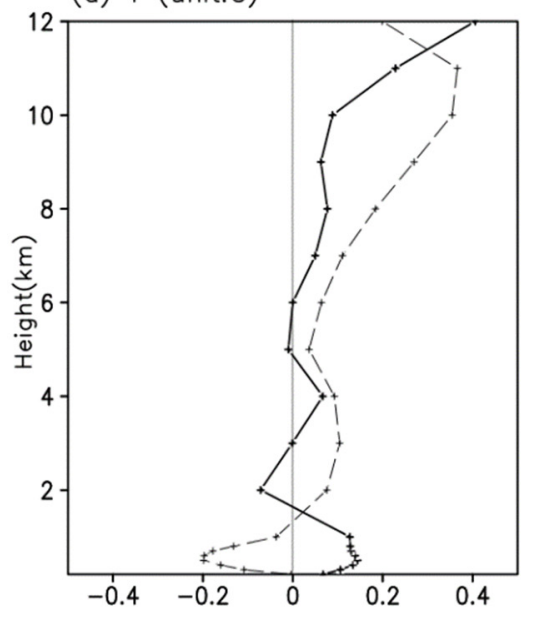

stable and induced descending airflow (solid line in Fig. 12(b)). Under these conditions, pollution did not diffuse efficiently.

However, under the aerosol indirect effect shown in Fig. 12(a) (dashed line), air temperature decreased by about $0.20^{\circ} \mathrm{C}$ at around $0.5-\mathrm{km}$ height but increased by about $0.3^{\circ} \mathrm{C}$ at heights of $1.5-13 \mathrm{~km}$, with maxima occurring at $3 \mathrm{~km}$ (by $\sim 0.16^{\circ} \mathrm{C}$ ) and $11 \mathrm{~km}$ (by $\sim 0.38^{\circ} \mathrm{C}$ ). These temperature maxima correspond to maxima in the LWC (dashed line in Fig. 6(a)), as well as the ice water content (IWC; dashed line in Fig. 6(b)). This is related to the formation of more clouds and microphysical latent heat release (dashed line in Fig. 6(c)).

The change in vertical velocity (as vertical profiles) over southern China is shown in Fig. 12(b) for the black box region of Fig. 5. The aerosol radiative effect produced a descending flow anomaly in southern China within the 1$12-\mathrm{km}$ layer, indicating that aerosols were not diffused but remained longer in the region, in turn potentially inducing further descent of air parcels. The aerosol indirect effect caused ascent within the troposphere of southern China, with a maximal vertical velocity increase of $\sim 4.1 \mathrm{~mm} \mathrm{~s}^{-1}$ at around $10-\mathrm{km}$ height. In this situation, aerosols dissipated more quickly. Generally, the ascent of air resulted in more precipitation, which enhanced removal of pollution.

As discussed earlier, Fig. 6 shows vertical profiles of (a) LWC ( $\left.\mathrm{mg} \mathrm{kg}^{-1}\right)$, (b) IWC ( $\mathrm{mg} \mathrm{kg}^{-1}$ ) and (c) microphysical latent heating $\left(\mathrm{K} \mathrm{day}^{-1}\right)$. The aerosol radiative effect decreased the LWC and IWC by about 8 and $1.9 \mathrm{mg} \mathrm{kg}^{-1}$, respectively. It also reduced microphysical latent heat release, because both localized atmospheric warming and air descent led to evaporation of clouds. In contrast, the aerosol indirect effect increased the LWC and IWC by about 14 and $1.1 \mathrm{mg} \mathrm{kg}^{-1}$, and increased the latent heat release. Overall, the reduction in the LWC related to the radiative effect was less than the increase related to the indirect effect, while the change in IWC showed the reverse trend. Overall, BB aerosols increased the formation of warm clouds but decreased the formation of ice clouds.

(b) W (unit: $\mathrm{mm} / \mathrm{s}$ )

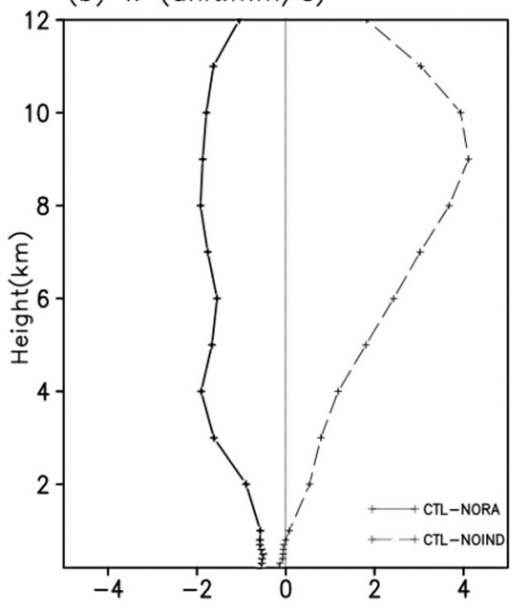

Fig. 12. Control (CTL) minus the no-aerosol-radiative-effect (NORA) model results representing the aerosol radiative effect as a black solid line and the CTL minus the no-aerosol-indirect-effect (NOIND) model results representing the aerosol indirect effect as a dashed line on regionally averaged monthly average vertical profiles of (a) temperature $\left({ }^{\circ} \mathrm{C}\right)$ and $(\mathrm{b})$ vertical velocity $\left(\mathrm{w}, \mathrm{mm} \mathrm{s}^{-1}\right.$ ) in southern China (defined by $21-27^{\circ} \mathrm{N}$ and $107-117^{\circ} \mathrm{E}$ ). 
Clearly, the atmospheric conditions resulting from aerosol effects feedback on aerosol dissipation. Under the aerosol indirect effect, the aerosol extinction coefficient was reduced by around $0.011 \mathrm{~km}^{-1}$ at 2-km height (not shown). However, it increased around $0.002 \mathrm{~km}^{-1}$ at $3-\mathrm{km}$ height over southernmost China related to radiative effect (not shown). Hence, atmospheric responses to the indirect effect in turn enabled aerosols to dissipate more readily over southern China than those related to the aerosol radiative effect.

\section{CONCLUSIONS}

In April 2013, there were abundant BB emissions from Indochina, far more than from other areas of Southeast Asia. Northern Laos had the highest BB emission levels (averaging $0.05 \mu \mathrm{g} \mathrm{m}^{-2} \mathrm{~s}^{-1}$ for $\mathrm{BC}$ and $0.25 \mu \mathrm{g} \mathrm{m}^{-2} \mathrm{~s}^{-1}$ for OC). Myanmar and Vietnam had slightly lower levels than Laos, with emissions of $0.02 \mu \mathrm{g} \mathrm{m}^{-2} \mathrm{~s}^{-1}$ for BC. These aerosols ascended via updrafts over local mountains in northern Indochina and traveled via tropospheric westerly winds to southern China and northern Pacific Ocean regions, having both radiative (direct and semi-direct) and indirect effects on the climate of Indochina and southern China.

1). Given the diverse BB aerosol spatial gradients, they had different and variable climate effects over southern China and Indochina, related to the radiative direct effect.

The maximum aerosol concentrations were below a $1-\mathrm{km}$ height over plains and valleys in Indochina. In these areas, aerosols were not concentrated enough to inhibit the formation of clouds related to heat absorption. Therefore, aerosols reduced the SWDOWN and surface temperature via the aerosol direct effect.

However, the aerosol semi-direct effect played an important role in southern China and over high-altitude areas of Indochina, such as the Annamite Range and the Tenasserim Hills, where aerosols had maximal concentrations at $\sim 2-\mathrm{km}$ height, coincident with conditions for warm cloud formation. Under this effect, aerosols absorbed solar radiation and evaporated cloud droplets, reducing LWC, IWC, and cloud cover. Less cloud cover (decrease by 7\%) and water vapor (decrease by $0.23 \mathrm{~g} \mathrm{~kg}^{-1}$ ) also reduced precipitation over southern China (by $1.09 \mathrm{~mm} \mathrm{day}^{-1}$ ) and northern Indochina, reducing wet deposition of aerosols. In addition, less cloud increased the SWDOWN by $8.97 \mathrm{~W} \mathrm{~m}^{-2}$, making surface temperature rise by $0.13^{\circ} \mathrm{C}$ in southern China. Therefore, the occurrence of less cloud contributed more to changing the solar radiation flux at the surface than the aerosol direct effect over southern China. Overall, the atmosphere becomes drier and hotter under the aerosol radiative effect in southern China.

2). Under the indirect aerosol effect, BB aerosols acting as $\mathrm{CCN}$ induced more cloud droplets and cloud cover over most of southern China, decreasing the SWDOWN by $27.46 \mathrm{~W} \mathrm{~m}^{-2}$, and surface temperature by $0.19^{\circ} \mathrm{C}$. Both the LWC and IWC increased markedly, releasing latent heat and promoting convection. Thus, pollution was diffused via ascending air. The precipitation decreased in middle reaches of the Yangtze River but increased over Guangxi Province. Overall, regional mean precipitation increased by $0.49 \mathrm{~mm} \mathrm{~d}^{-1}$ over southern China. Therefore, the atmosphere becomes moister (with water vapor mixing ratios increase of $0.40 \mathrm{~g} \mathrm{~kg}^{-1}$ ) and colder under the aerosol indirect effect in southern China, just opposite to the changes related to radiative effect.

$3)$. In general, atmospheric responses to indirect effect in turn enable aerosols to dissipate more readily over southern China than those related to their radiative effect. The aerosol extinction coefficient was reduced by around $0.011 \mathrm{~km}^{-1}$ at 2-km height in southern China as a result of increased precipitation in Guangxi Province and ascent of air parcels over southern China related to the aerosol indirect effect. However, as a result of this reduced precipitation, extra descending air and northeasterly winds over southern China, linked to the radiative effect, inhibited the wet deposition, diffusion, and westward transport of aerosols. As a result, the aerosol extinction coefficient increased around $0.002 \mathrm{~km}^{-1}$ at $3-\mathrm{km}$ height over southernmost China. Therefore, the aerosol indirect effect played a bigger role in removing BB aerosols from the atmosphere than the radiative effect. Under solely aerosol radiative effect, BB particles would remain longer in the air.

This paper considers climate impacts related to $\mathrm{BB}$ aerosols, investigating the aerosol radiative effect and indirect effect separately. According to the above conclusions, the atmospheric conditions in southern China resulting from BB aerosols from distant Indochina should be considered when accounting for climatic change or other meteorological variation over southern China. Given that this study reviewed one month of $\mathrm{BB}$ emissions, our results lack universality. Ideally, we need to simulate longer periods using diverse atmospheric chemical models in future studies.

\section{ACKNOWLEDGEMENTS}

The authors were supported by the National Key R\&D Program of China (2018YFC1507402), the National Program for Key Basic Research Projects of China (973) (Grant no. 2014CB953904), National Natural Science Foundation of China (NSFC; Grant no. 41705117 and 41875168), and Guangzhou Science and Technology Plan (201605131033247). We are also grateful to the NCAR Mesoscale and Microscale Meteorology Division for making the WRF-Chem model available at http://www.mmm.ucar.edu/wrf/users. The National Centers for Environmental Prediction-Final Global tropospheric analysis data (NCEP-FNL; http://rda.ucar.edu/ datasets/ds083.2), the $0.5^{\circ} \times 0.5^{\circ}$ Reanalysis of Tropospheric chemical composition (RETRO; http:/retro.enes.org/index. shtml), and the $1^{\circ} \times 1^{\circ}$ Emission Database for Global Atmospheric Research (EDGAR; http://www.mnp.nl/edgar/ introduction) were used in this paper.

\section{REFERENCES}

Ackerman, A.S., Toon, O.B., Stevens, D.E., Heymsfield, A.J., Ramanathan, V.V. and Welton, E.J. (2000). Reduction of tropical cloudiness by soot. Science 288: 1042-1047.

Ackermann, I.J., Hass, H., Memmesheimer, M., Ebel, A., Binkowski, F.S. and Shankar, U. (1998). Modal aerosol 
dynamics model for Europe: Development and first applications. Atmos. Environ. 32: 2981-2999.

Albrecht, B.A. (1989). Aerosols, cloud microphysics, and fractional cloudiness. Science 245: 1227-1230.

Andela, N., Schultz, M., Van, d.W., G. R, Van Leeuwen, T.T., Kaiser, J.W., Wooster, M.J., Heil, A. and Remy, S. (2013). Assessment of the Global Fire Assimilation System (GFASv1), MACC-II Deliverable D_31.2. https://www.ecmwf.int/en/elibrary/7707-assessmentglobal-fire-assimilation-system-gfasv 1

Carmichael, G.R., Tang, Y., Kurata, G., Uno, I., Streets, D.G., Thongboonchoo, N., Woo, J.H., Guttikunda, S., White, A., Wang, T., Blake, D.R., Atlas, E., Fried, A., Potter, B., Avery, M.A., Sachse, G.W., Sandholm, S.T., Kondo, Y., Talbot, R.W., Bandy, A., Thorton, D. and Clarke, A.D. (2003). Evaluating regional emission estimates using the TRACE-P observations. J. Geophys. Res. 108: D218810.

Chang, J.S., Brost, R.A., Isaksen, I.S.A., Madronich, S., Middleton, P., Stockwell, W.R. and Walcek, C.J. (1987). A three-dimensional Eulerian acid deposition model: Physical concepts and formulation. J. Geophys. Res. 92: 14681-14700.

Charlson, R.J., Schwartz, S.E., Hales, J.M., Cess, R.D., Coakley, J.A., Hansen, J.E. and Hofmann, D.J. (1992). Climate forcing by anthropogenic aerosols. Science 255: 423-430.

Chen, F., and Dudhia, J. (2001). Coupling an advanced land surface-hydrology model with the Penn State-NCAR MM5 modeling system. Part I: Model implementation and sensitivity. Mon. Weather Rev. 129: 569-585.

Chen, J., Li, C., Ristovski, Z., Milic, A., Gu, Y., Islam, M.S., Wang, S., Hao, J., Zhang, H. and He, C. (2016). A review of biomass burning: Emissions and impacts on air quality, health and climate in China. Sci. Total Environ. 579: 1000-1034.

Daniel, R., Jin, D., Xing, Y., Zhanyu, Y., Xiaohong, X., Xing, Y. and Chuanli, D. (2007). Inverse relations between amounts of air pollution and orographic precipitation. Science 315: 1396-1398.

Daniel, R., Ulrike, L., Raga, G.B., O'Dowd, C.D., Markku, K., Sandro, F., Anni, R. and Andreae, M.O. (2008). Flood or drought: How do aerosols affect precipitation? Science 321: 1309-1313.

Ding, A.J., Huang, X., Nie, W., Sun, J.N., Kerminen, V.M., Petäjä, T., Su, H., Cheng, Y.F., Yang, X.Q. and Wang, M.H. (2016). Enhanced haze pollution by black carbon in megacities in China. Geophys. Res. Lett. 43: 2873-2879.

Ek, M.B., Mitchell, K.E., Lin, Y., Rogers, E., Grunmann, P., Koren, V., Gayno, G. and Tarpley, J.D. (2003). Implementation of Noah land surface model advances in the National Centers for Environmental Prediction operational mesoscale Eta model. J. Geophys. Res. 108: 8851.

Fan, J., Leung, L.R., DeMott, P.J., Comstock, J.M., Singh, B., Rosenfeld, D., Tomlinson, J.M., White, A., Prather, K.A., Minnis, P., Ayers, J.K. and Min, Q. (2014). Aerosol impacts on California winter clouds and precipitation during CalWater 2011: Local pollution versus long-range transported dust. Atmos. Chem. Phys. 14: 81-101.

Flemming, J. (2012). Global reactive gases forecasts and reanalysis in the MACC project. J. Integr. Environ. Sci. 9: 57-70.

Fu, J.S., Hsu, N.C., Gao, Y., Huang, K., Li, C., Lin, N.H. and Tsay, S.C. (2012). Evaluating the influences of biomass burning during 2006 BASE-ASIA: A regional chemical transport modeling. Atmos. Chem. Phys. 12: 3837-3855.

Ge, C., Wang, J. and Reid, J.S. (2014). Mesoscale modeling of smoke transport over the Southeast Asian Maritime Continent: Coupling of smoke direct radiative feedbacks below and above the low-level clouds. Atmos. Chem. Phys. 14: 159-174.

Giglio, L., Csiszar, I. and Justice, C.O. (2006a). Global distribution and seasonality of active fires as observed with the Terra and Aqua Moderate Resolution Imaging Spectroradiometer (MODIS) sensors. J. Geophys. Res. 111: G02016.

Giglio, L., van der Werf, G.R., Randerson, J.T., Collatz, G.J. and Kasibhatla, P. (2006b). Global estimation of burned area using MODIS active fire observations. Atmos. Chem. Phys. 6: 957-974.

Grell, G.A. and Dévényi, D. (2002). A generalized approach to parameterizing convection combining ensemble and data assimilation techniques. Geophys. Res. Lett. 29:587590.

Grell, G.A., Schmitz, P.R., Mckeen, S.A., Frost, G., Skamarock, W.C. and Eder, B. (2005). Fully coupled "online" chemistry within the WRF model. Atmos. Environ. 39: 6957-6975.

Hansen, J., Sato, M. and Ruedy, R. (1997). Radiative forcing and climate response. J. Geophys Res. 102: 6831-6864.

Hao, W.M. and Liu, M.H. (1994). Spatial and temporal distribution of tropical biomass burning. Global Biogeochem. Cycles 8: 495-503.

Hong, S.Y., Noh, Y. and Dudhia, J. (2006). A new vertical diffusion package with an explicit treatment of entrainment processes. Mon. Weather Rev. 134: 2318-2341.

Huebert, B.J., Bates, T., Russell, P.B., Shi, G., Kim, Y.J., Kawamura, K., Carmichael, G. and Nakajima, T. (2003). An overview of ACE-Asia: Strategies for quantifying the relationships between Asian aerosols and their climatic impacts. J. Geophys. Res. 108: 8633.

Iacono, M.J., Mlawer, E.J., Clough, S.A. and Morcrette, J.J. (2000). Impact of an improved longwave radiation model, RRTM, on the energy budget and thermodynamic properties of the NCAR community climate model, CCM3. J. Geophys. Res. 105: 14873-14890.

IPCC (2007). Impacts, adaptation, and vulnerability. In Climate Change 2007. Parry, M.L., Canziani, O.F., Palutikof, J.P., van der Linden, P.J., Hanson, C.E. (Eds.), Cambridge University Press, United Kingdom.

IPCC (2018). Global Warming of $1.5^{\circ} \mathrm{C}$. An IPCC Special Report on the impacts of global warming of $1.5^{\circ} \mathrm{C}$ above pre-industrial levels and related global greenhouse gas emission pathways, in the context of strengthening the global response to the threat of climate change, sustainable development, and efforts to eradicate poverty. In Climate 
Change 2007. Masson-Delmotte, V., Zhai, P., Pörtner, H.O., Roberts, D., Skea, J., Shukla, P.R., Pirani, A., Moufouma-Okia, W., Péan, C., Pidcock, R., Connors, S., Matthews, J.B.R., Chen, Y., Zhou, X., Gomis, M.I., Lonnoy, E., Maycock, T., Tignor, M. and Waterfield, T. (Eds.), Cambridge University Press, Cambridge, United Kingdom.

Jacob, D.J., Crawford, J.H., Kleb, M.M., Connors, V.S., Bendura, R.J., Raper, J.L., Sachse, G.W., Gille, J.C., Emmons, L. and Heald, C.L. (2003). Transport and Chemical Evolution over the Pacific (TRACE-P) aircraft mission: Design, execution, and first results. J. Geophys. Res. 108: 900.

Jacobson, M.Z. (2012). Air pollution and global warming. Cambridge University Press, Cambridge, United Kingdom.

Johnson, B.T., Shine, K.P. and Forster, P.M. (2010). The semi-direct aerosol effect: Impact of absorbing aerosol on marine stratocumulus. Q. J. R. Meteorolog. Soc. 130: 1407-1422.

Kaiser, J.W., Heil, A., Andreae, M.O., Benedetti, A., Chubarova, N., Jones, L., Morcrette, J.J., Razinger, M., Schultz, M.G. and Suttie, M. (2012). Biomass burning emissions estimated with a global fire assimilation system based on observed fire radiative power. Biogeosciences 9: 527-554.

Kaiser, J.W., Andela, N., Heil, A., Paugam, R., Schultz, M.G., van der Werf, G.R., Wooster, M.J. and Remy, S. (2013). Recent developments in Fire Emission Monitoring in MACC-II using Fire Radiative Power Observations. EGU General Assembly 2013, held 7-12 April, 2013 in Vienna, Austria.

Kim, M.K., Lau, W.K.M., Chin, M., Kim, K.M., Sud, Y.C. and Walker, G.K. (2006). Atmospheric teleconnection over Eurasia induced by aerosol radiative forcing during boreal spring. J. Clim. 19: 4700-4718.

Lau, K.M., Kim, M.K. and Kim, K.M. (2006). Asian summer monsoon anomalies induced by aerosol direct forcing: The role of the Tibetan Plateau. Clim. Dyn. 26: 855-864.

Lee, D., Sud, Y.C., Oreopoulos, L., Kim, K.M., Lau, W.K. and Kang, I.S. (2014). Modeling the influences of aerosols on pre-monsoon circulation and rainfall over Southeast Asia. Atmos. Chem. Phys. 14: 6853-6866.

Lee, S.S., Feingold, G., Mccomiskey, A., Yamaguchi, T., Koren, I., Vanderlei Martins, J. and Yu, H. (2015). Effect of gradients in biomass burning aerosol on shallow cumulus convective circulations. J. Geophys. Res. 119: 9948-9964.

Li, J., Zhang, Y., Wang, Z., Sun, Y., Fu, P., Yang, Y., Huang, H., Li, J., Zhang, Q., Lin, C. and Lin, N.H. (2017). Regional impact of biomass burning in southeast Asia on atmospheric aerosols during the 2013 Seven South-East Asian studies project. Aerosol Air Qual. Res. 17: 2924 2941.

Lin, N.H., Tsay, S.C., Maring, H.B., Yen, M.C., Sheu, G.R., Wang, S.H., Chi, K.H., Chuang, M.T., Ou-Yang, C.F. and $\mathrm{Fu}$, J.S. (2013). An overview of regional experiments on biomass burning aerosols and related pollutants in Southeast Asia: From BASE-ASIA and the Dongsha
Experiment to 7-SEAS. Atmos. Environ. 78: 1-19.

Lin, N.H., Sayer, A.M., Wang, S.H., Loftus, A.M., Hsiao, T.C., Sheu, G.R., Hsu, N.C., Tsay, S.C. and Chantara, S. (2014). Interactions between biomass-burning aerosols and clouds over southeast Asia: Current status, challenges, and perspectives. Environ. Pollut. 195: 292-307.

Lin, Y.L., Farley, R.D. and Orville, H.D. (1983). Bulk parameterization of the snow field in a cloud model. $J$. Appl. Meteorol. 22: 1065-1092.

Matus, A.V. and L'Ecuyer, T.S. (2017). The role of cloud phase in Earth's radiation budget. J. Geophys. Res. 122: 2559-2578.

Meehl, G.A., Arblaster, J.M. and Collins, W.D. (2006). Effects of black carbon aerosols on the Indian monsoon. J Clim. 21: 2869-2882.

Menon, S., Hansen, J., Nazarenko, L. and Luo, Y. (2002). Climate effects of black carbon aerosols in China and india. Science 297: 2250-2253.

Mlawer, E.J., Taubman, S.J., Brown, P.D., Iacono, M.J. and Clough, S.A. (1997). Radiative transfer for inhomogeneous atmospheres: RRTM, a validated correlated-k model for the longwave. J. Geophys. Res. 102: 16663-16682.

Pani, S.K., Lin, N.H., Chantara, S., Wang, S.H., Khamkaew, C., Prapamontol, T. and Janjai, S. (2018). Radiative response of biomass-burning aerosols over an urban atmosphere in northern peninsular Southeast Asia. Sci. Total Environ. 633: 892-911.

Reid, J.S., Hyer, E.J., Johnson, R.S., Holben, B.N., Yokelson, R.J., Zhang, J., Campbell, J.R., Christopher, S.A., Girolamo, L.D. and Giglio, L. (2013). Observing and understanding the Southeast Asian aerosol system by remote sensing: An initial review and analysis for the Seven Southeast Asian Studies (7SEAS) program. Atmos. Res. 122: 403-468.

Rieland, M. and Stuhlmann, R. (1993). Toward the influence of clouds on the shortwave radiation budget of the earth-atmosphere system estimated from satellite data. J. Appl. Meteorol. 32: 825-843.

Schell, B., Ackermann, I.J., Hass, H., Binkowski, F.S. and Ebel, A. (2001). Modeling the formation of secondary organic aerosol within a comprehensive air quality model system. J. Geophys. Res. 106: 28275-28293.

Spencer, M.T., Holecek, J.C., Corrigan, C.E., Ramanathan, V. and Prather, K.A. (2008). Size-resolved chemical composition of aerosol particles during a monsoonal transition period over the Indian Ocean. J. Geophys. Res. 113: D16305.

Tao, W.K., Chen, J.P., Li, Z., Wang, C. and Zhang, C. (2012). Impact of aerosols on convective clouds and precipitation. Rev. Geophys. 50: RG2001.

Twomey, S.A. (1977). The influence of pollution on the shortwave albedo of clouds. J. Atmos. Sci. 34: 11491154.

Wang, S.H., Welton, E.J., Holben, B.N., Tsay, S.C., Lin, N.H., Giles, D., Stewart, S.A., Janjai, S., Nguyen, X.A., Hsiao, T.C., Chen, W.N., Lin, T.H., Buntoung, S., Chantara, S. and Wiriya, W. (2015). Vertical distribution and columnar optical properties of springtime biomass-burning aerosols over northern Indochina during 2014 7-SEAS 
campaign. Aerosol Air Qual. Res. 15: 2037-2050.

Wang, S.H., Lin, N.H., Chou, M.D. and Woo, J.H. (2007). Estimate of radiative forcing of Asian biomass-burning aerosols during the period of TRACE-P. J. Geophys. Res. 112: D10222.

Wu, L., Hui, S. and Jiang, J.H. (2011a). Regional simulations of deep convection and biomass burning over South America: 1. Model evaluations using multiple satellite data sets. J. Geophys. Res. 116: D17208.

Wu, L., Su, H. and Jiang, J.H. (2011b). Regional simulations of deep convection and biomass burning over South America: 2. Biomass burning aerosol effects on clouds and precipitation. J. Geophys. Res. 116: D17209.

Xiao, H., Yin, Y., Jin, L., Chen, Q., Chen, J., Xiao, H., Yin, Y., Jin, L. and Chen, Q. (2014). Simulation of aerosol effects on orographic clouds and precipitation using WRF model with a detailed bin microphysics scheme. Atmos. Sci. Lett. 15: 134-139.

Xiao, H., Yin, Y., Jin, L., Chen, Q. and Chen, J. (2015).
Simulation of the effects of aerosol on mixed-phase orographic clouds using the WRF model with a detailed bin microphysics scheme. J. Geophys. Res. 120: 83458358.

Zhang, Y., Fu, R., Yu, H., Dickinson, R.E., Juarez, R.N., Chin, M. and Wang, H. (2008). A regional climate model study of how biomass burning aerosol impacts landatmosphere interactions over the Amazon. J. Geophys. Res. 113: D14S15.

Zhang, Y., Fu, R., Yu, H., Qian, Y., Dickinson, R., Silva Dias, P.L.D. and Fernandes, K. (2009). Impact of biomass burning aerosol on the monsoon circulation transition over Amazonia. Geophys. Res. Lett. 36: L10814.

Received for review, February 23, 2019

Revised, August 5, 2019

Accepted, October 17, 2019 